\title{
RELEVANT RESEARCH OF ADMINISTRATIVE ASPECTS IN ENSURING THE DEFENSE OF UKRAINE (REVIEW OF V.Y. PASHYNSKY'S MONOGRAPH "ENSURING DEFENSE OF UKRAINE: ADMINISTRATIVE AND LEGAL ASPECTS") ${ }^{1}$
}

Rostislav Kaliuzhnyi, Deputy Director of the Educational and Research Law Institute of the National Aviation University,

Doctor of Jurisprudence, Professor
The monograph of V.Y. Pashynskyi "Ensuring defense of Ukraine: administrative and legal aspects" is a comprehensive scientific research of the relevant theoretical and practical problems of administrative provision of state defense at the present stage of the development of the statehood of Ukrainian people. The monographic research is timely and relevant taking into account the need for conducting defense reform and the establishment of an effective system of defense of the state in the difficult conditions of Russian armed aggression, the "hybrid war" against Ukraine.

The author of the scientific paper has carried out the research of the following problems: theoretical and legal foundations of ensuring defense of Ukraine; methodological principles and status of administrative provision of state defense; specific features of administrative and legal status of the subjects of ensuring defense of Ukraine (state authorities and civil society); legal status, functions and tasks, features of administrative provision of the activity of the Armed Forces of Ukraine and other components of the defense forces in the system of the state defense; the ways to improve administrative and legal provision of Ukraine's defense in the light of modern national and international experience.

The monograph contains a clear and detailed comparative and legal analysis of the norms of the current national legislation in the sphere of Ukraine's defense and NATO member states, which is due to the intensification of the process of Ukraine's integration into the structures of the North Atlantic Alliance. Particular attention is focused on determining directions and implementation of modern approaches in regard to administrative and legal provision of defense of Ukraine, taking into account international experience and NATO standards in the field of defense and military and administrative sphere of public relations.

\footnotetext{
${ }^{1}$ Пашинський В.Й. Забезпечення оборони України: адміністративно-правові аспекти : монографія. Київ : ФОП Маслаков, 2018. 408 с.

Pashynskyi V.Y. Zabezpechennia oborony Ukrainy: administratyvno-pravovi aspekty: monohrafiia [Ensuring defense of Ukraine: administrative and legal aspects: monograph]. Kyiv: FOP Maslakov, 2018. 408 p. [in Ukrainian].
} 


\section{РЕЦЕНЗІї}

The research of the legal nature, the essence, components of the state defense and its administrative and legal provision, accomplished by the author of the monograph is positive. There are issues among them that deserve particular attention, namely: the place of defense as a state and legal phenomenon within the legal system of the state, legal science, the system of ensuring national security and defense; conceptual and methodological foundations of administrative and legal provision of defense (essence and content, structure, objective, tasks); the system of public administration of the state defense and all components of the security and defense sector; definition of the concept, content and essence of administrative and legal relations in the field of defense; clarification of administrative and legal status of the subjects of ensuring defense and division of their powers, the formation of the system of democratic civilian control in the field of defense. The author correctly and scientifically substantiated lists the following characteristic features of administrative and legal provision of the defense of Ukraine: the development of key theoretical and practical issues of administrative and legal provision of the state defense; organizational and managerial activity in the field of defense; normative activity related to the development and adoption of legislative acts defining the legal framework of the defense, subordinate regulatory acts of the head of the state, agencies of executive power, agencies of local self-government and agencies of military management (military command) on defense issues; organization of legal work (legal provision) on effective implementation, in particular, the application, acts of military management in the activities of the subjects ensuring the state defense. The author logically and convincingly substantiates the conclusion that it is impossible to organize and carry out the state defense, to conduct an effective defense reform without the implementation of measures of administrative and legal provision.

Important scientific novelty is also observed in the author's periodization of the formation and development of the system of the state defense; scientific substantiation of the content and structure of administrative and legal relations in the field of defense of Ukraine; the allocation of military and administrative law as a sphere of Ukraine's defense; the allocation of military and administrative law as an independent institutional entity, an independent sub-branch in the system of Special Administrative Law; the classification of social relations in the field of defense that influence on the formation of military and administrative law; the classification of characteristic features, structure and subjects of administrative and legal provision of Ukraine's defense; the classification of the functions of Verkhovna Rada of Ukraine, the Cabinet of Ministers of Ukraine, the President of Ukraine as the Supreme Allied Commander, the National Security and Defense Council of Ukraine, the Civil Society within the system of subjects of legal provision of Ukraine's defense; the author's classification of characteristic features and structure of administrative and legal provision of the activity of the Armed Forces of Ukraine; the allocation of characteristic features of the Armed Forces of Ukraine as a special agency (institution) of the state; propositions for improving the system of administration of defense forces based on the distribution of powers, functions, tasks, responsibilities and responsibilities in the field of defense, which are in line with the principles adopted in the NATO member states, etc. 
A notable scientific significance has refinement and improvement of conceptual and categorical apparatus in the field of state defense accomplished in this monographic research. In particular, the following author's definitions are important and well-considered: "Ukraine's defense", "administrative and legal provision of Ukraine's defense", "subjects of administrative and legal provision of the defense of Ukraine", "administrative and legal status of the subjects of administrative and legal provision of the defense of Ukraine", "military and administrative relations", "military and administrative legislation", "National Defense Forces of Ukraine", "Supreme Commander-in-Chief of the National Defense Forces of Ukraine", etc.

A considerable number of used and analyzed scientific sources and regulatory acts, scientific works of domestic and foreign scholars in law field provide reasoning and objectivity of the research results. Thoroughness and comprehensiveness of the research, which made it possible to make concrete and logical theoretical conclusions, practical propositions and recommendations concerning the ways of improving administrative and legal provision of Ukraine's defense, are valuable characteristics of the monograph.

The author of the monograph scientifically reasoned the necessity of working out draft laws and adopting new laws of Ukraine "On National Defense of Ukraine", "On the Commissioner of Verkhovna Rada of Ukraine on Security and Defense Sector Issues", which should become an important part of administrative and legal provision of defense, will legislatively establish the present state of social relations in the field of defense, principles of public administration of the state defense system according to NATO standards.

The work is written in modern business Ukrainian, with the use of legal terminology, logical and consistent presentation of the material, the main provisions and conclusions of the monograph.

All this provides grounds for asserting the author's scientific maturity, his ability to research and solve complex scientific issues regarding the development of administrative law, and, based on the obtained results to outline the perspectives for further scientific research in this field in the context of military and administrative legal relations.

Taking into account the aforementioned, comprehensive scientific monographic study accomplished by V.Y. Pashynskyi undeniably has a significant value for further development of administrative science in the system of law of Ukraine, for studying problems of military and administrative law. It is carried out at a high scientific and theoretical level, contains new scientifically grounded results, which totally solve the scientific problem, which consists in the development of the conceptual provisions of the theory and practice of administrative and legal provision of the defense of Ukraine. 